\author{
名和秀起, 千堂年昭*
}

岡山大学医学部・歯学部附属病院 薬剂部

\title{
Drug interaction
}

\section{(15. combination with $\mathrm{H}_{2}$-receptor antagonist)}

\section{Hideki Nawa, Toshiaki Sendo*}

Department of Pharmacy, Okayama University Hospital

\section{はじめに}

胃潰瘍発生，病態については，胃 酸・ペプシンなどの胃酸攻撃因子 と, 胃粘液, 血流などの防御因子か らなるバランス説が支配的であり， 治療的にもこの理論に即して実施さ れてきた。つまり, 胃酸は消化性潰 瘍の発生に必須であり, かつ中心的 な役割を果たしていると考えられて きた。事実, 十二指腸潰瘍は高酸で あり，またガストリン産生腫瘍では 高頻度に十二指腸潰瘍が発症する。 さらに潰瘍治療においては, 胃潰瘍, 十二指腸潰瘍ともに酸分泌抑制薬が 最も効果的であることは古くから知 られていた。またその治癒効果は酸 分泌の程度が強いほど高いことが明 らかとなっている11.

胃潰瘍治療に用いられる薬剤は, 攻撃因子の抑制および防御因子の増 強を目的とした薬剤, そしてへリコ バクターピロリー除菌治療薬とに分 けて考えると理解しやすい（表 1 ).

平成 20 年 12 月受理

* $7700-8558$ 岡山市鹿田町 2-5-1

電話：086-235-7640

FAX : 086-235-7794

E-mail : sendou@md.okayama-u.ac.jp

\section{薬物相互作用}

消化性潰瘍の治療薬として用いら れる $\mathrm{H}_{2}$ 遮断薬は, 胃酸分泌抑制や肝 臓の薬物代謝酵素の一つであるチト クローム P 450の活性阻害を有する ことから, 併用薬物の薬効に大きな 影響を与えることが知られている。

最初に臨床応用されたシメチジン は血中濃度半減期が短いために使用 しやすく，さらに即効性であるとい う利点を有しているが, 他の $\mathrm{H}_{2}$ 遮断 薬に比べて強い薬物代謝阻害作用を 有するために問題となる場合が多い.
ニトイン，ワルファリンなどと相互 作用はよく知られており, 肝代謝率 が高く治療域の狭い薬剤はシメチジ ンとの併用により血中濃度が上昇 し，中毒に至る可能性があるので注 意を要する ${ }^{2)}$.

シメチジンの薬物代謝酵素の阻害 はその分子中のイミダゾール環によ るとされており，その後開発された $\mathrm{H}_{2}$ 遮断剂は分子中にイミダゾール 環を持たず，したがってこれらの薬 剂では相互作用は起こらない可能性 が指摘されている（図１）。

$$
\text { シメチジンとテオフィリン, フェ }
$$
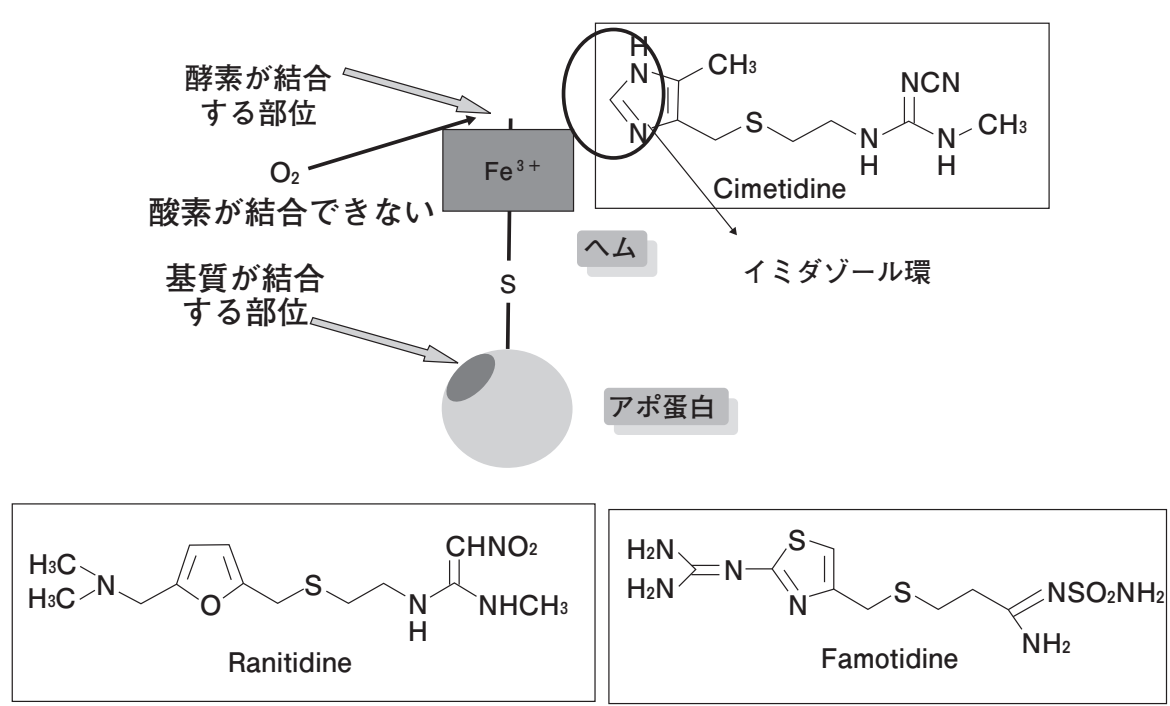

図 1 P-450の模式図とイミダゾール環をもつヒスタミン $\mathrm{H}_{2}$ 遮断薬 
シメチジンの薬物相互作用 ${ }^{2)}($ 表 2 )

1. 肝での薬物代謝阻害（P-450の 阻害, 肝血流量の低下)

シメチジン併用による臨床上最も 重要な薬物相互作用は, 肝薬物代謝 酵素の阻害を引き起こし, 併用薬物 の薬物代謝を低下させる。

\section{2.胃酸分泌抑制による吸収の変動}

$\mathrm{H}_{2}$ 遮断薬の胃酸分泌抑制により 胃内 $\mathrm{pH}$ が上昇するため, 内服した 薬剤の吸収に影響を与えることがあ る。通常は塩基性薬剤の吸収は増加 し, 逆に酸性薬郕は減少する。

3. 肝血流量の減少による肝クリア ランスの低下

シメチジンは肝の薬物代謝酵素を
阻害するだけでなく，肝血流量を減 少させることによって肝のクリアラ ンスを低下させる作用を持つ。

\section{4. 腎クリアランスの減少}

シメチジンはプロカインアミドの 腎からの排泄を抑制し，その血中濃 度を上昇されることが報告されてい る。これは腎の近位尿細管からの能 動的な排泄の拮抗作用に基づくと考

表 1 胃潰瘍治療薬

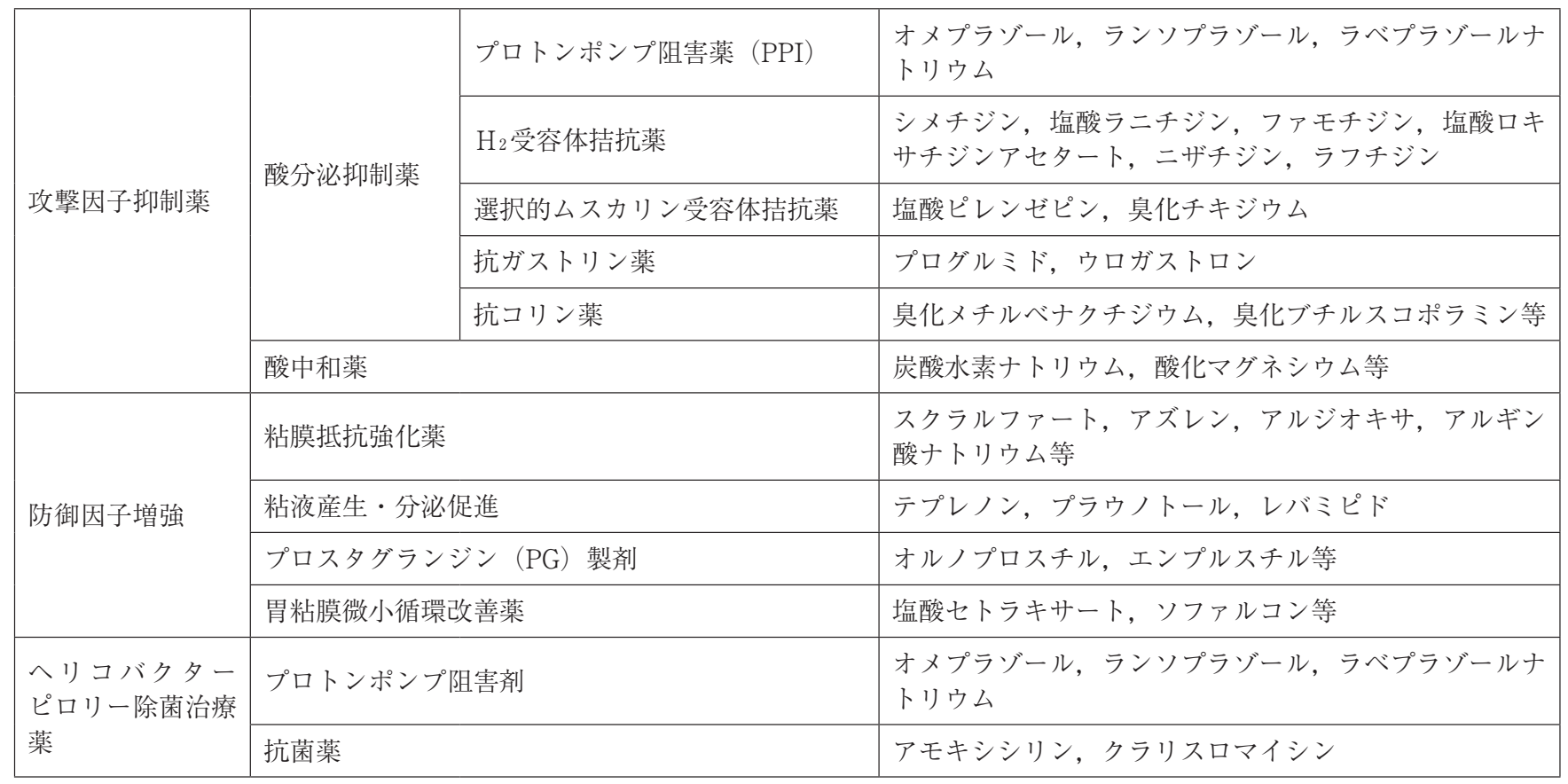

表 2 シメチジンの添付文章に記載された相互作用

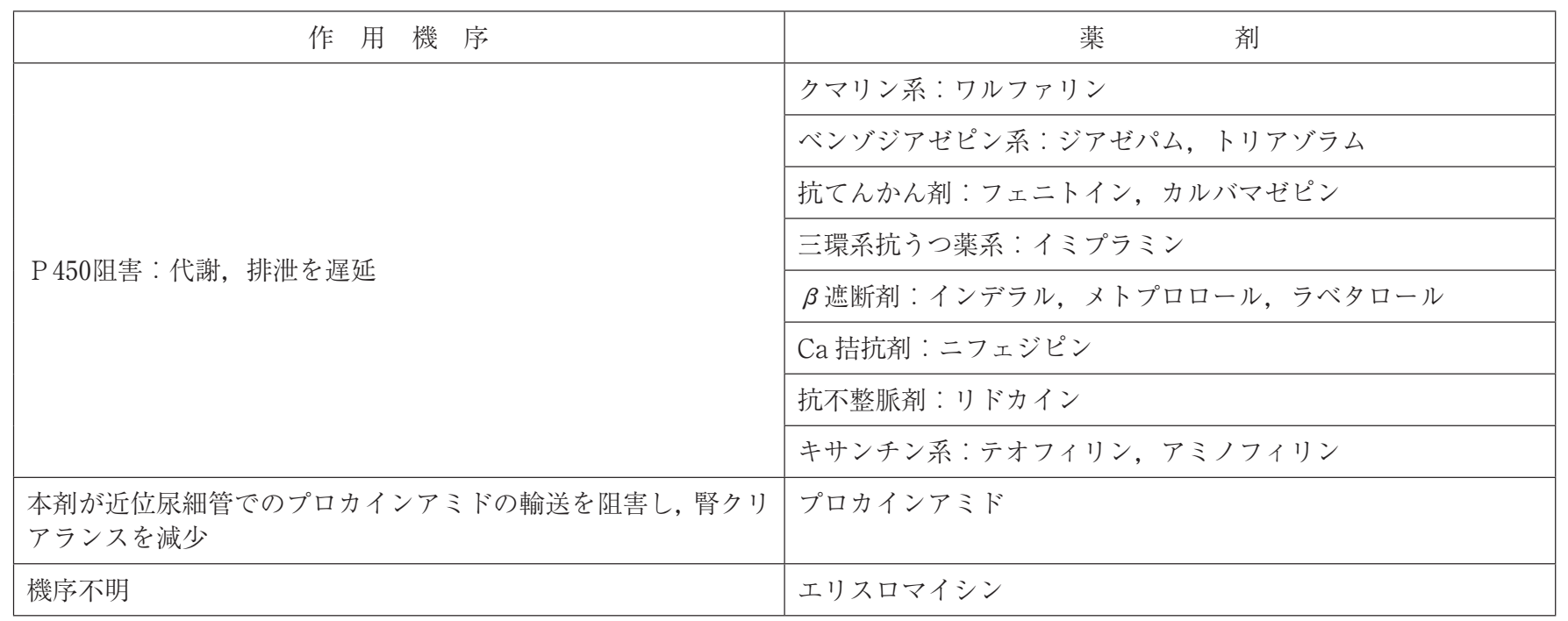


表 3 他の $\mathrm{H}_{2}$ 受容体について添付文書上に相互作用として薬剤の血中濃度が低下する報告のあるものを記す 3 -8

\begin{tabular}{|c|c|c|}
\hline $\mathrm{H}_{2}$ 遮断剂名 & 相互作用の報告がある薬剤 & 機序・危険因子 \\
\hline ファモチジン & アゾール系抗真菌薬：イトラコナゾール & 胃酸分泌抑制作用が薬剂の経口吸収を低下させる \\
\hline \multirow{3}{*}{ ニザチジン } & ゲフィチニブ & $\begin{array}{l}\text { 薬剤の溶解性が } \mathrm{pH} \text { に依存することから, 胃内 } \mathrm{pH} \text { が持続的に上 } \\
\text { 昇した条件下において, 薬風の吸収が低下し, 作用が減弱するお } \\
\text { それがある. }\end{array}$ \\
\hline & 合成抗菌剤 プルリフロキサシン & 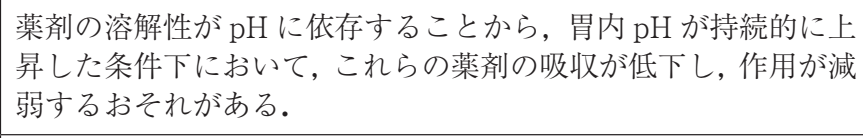 \\
\hline & 硫酸アタザナビル & 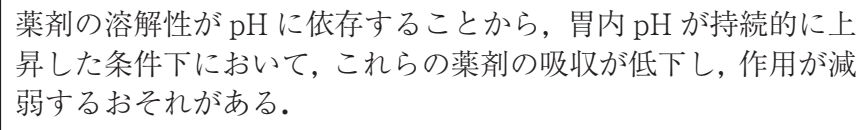 \\
\hline ラニチジン & なし & なし \\
\hline ロキサチジン & なし & なし \\
\hline ラフチジン & なし & なし \\
\hline
\end{tabular}

えられている。

\section{5 . 神経一筋遮断作用の增強}

シメチジンはコリンエステラーゼ 阻害作用を持ち，そのために非脱分 極性筋弛緩剂やアミノ糖系抗生物質 の神経一遮断作用を増強することが 報告されている。

\section{6. $\mathrm{H}_{2}$ 受容体遮断作用による薬理 作用の修飾}

$\mathrm{H}_{2}$ 受容体は胃壁細胞以外にも心 臟や中枢神経等にも存在することが 知られている. $\mathrm{H}_{2}$ 遮断剂での投与に より, 時として胃壁細胞以外の $\mathrm{H}_{2}$ 受 容体が遮断され併用薬剤の作用が修 飾されることがある。

\section{シメチジン以外の $\mathrm{H}_{2}$ 遮断剤の薬物}

\section{相互作用}

薬物相互作用については, $\mathrm{H}_{2}$ 遮断
剂の薬理作用や生体内動態と関連す るものなので, シメチジンに特異的 なものとはなりえない。逆に胃酸分 泌抑制作用や抗コリンエステラーゼ 作用はシメチジンよりも他の $\mathrm{H}_{2}$ 遮 断剤の方が強いとされており，より 慎重に投与すべきである。

このように $\mathrm{H}_{2}$ 遮断剂の相互作用 はさまざまな機序で発生する，時に は一つの組み合わせに同時に複数の 機序が関与している場合がある。相 互作用は必ずしも単純ではなく，い くつもの作用機序を一つ一つ丁寧に 検討していくことが必要である．個 々の薬剤の特性を踏まえて総合的に 判断する姿勢が求められる（表 3 ).

\section{文献}

1) 胃潰瘍ガイドラインの適用と評価に
関する研究班：EBMに基づく胃潰瘍 診療ガイドライン第二版, じほう, 東 京 (2007).

2 ) 堀美智子：医薬品相互作用ハンドブ ック改定第二版, じほう, 東京 (2002).

3 ） ガスター D錠添付文書, アステラス製 薬株式会社, 東京 (2005)。

4 ）アシノン錠添付文書, ゼリア新薬株式 会社，東京（2008）。

5 ）ザンタック錠添付文書, グラクソスミ スクライン株式会社，東京（2008）。

6 ）アルタットカプセル添付文書, あすか 製薬株式会社，東京（2007）。

7 ）プロテカジン錠添付文書, 大鵬薬品工 業株式会社, 東京 (2006).

8 ) 水柿道直：ヒスタミン $\mathrm{H}_{2}$ 遮断薬 (シ メチジン)による代謝阻害. 治療 (1994) 76，47-52. 